\title{
Severe hypotension from epidural meperidine in a high-risk patient after thoracotomy
}

A sixty-eight-year-old female developed severe hypotension immediately after the administration of epidural meperidine for post-thoracotomy pain. Two preceding injections of epidural opiates had been unevenfful. The cardiovascular collapse was difficult to reverse and may have contributed to the patient's subsequent death. Cardiovascular complications have not been reported frequently as a possible side effect of epidural opiate analgesia.

The administration of narcotics via the epidural route is increasingly used to relieve postoperative pain. It has been suggested that epidural anaesthesia and analgesia lead to a lower postoperative morbidity' in high-risk patients.

A case is described in which epidural administration of $50 \mathrm{mg}$ meperidine diluted in $10 \mathrm{ml}$ normal saline solution was followed shortly by unexpected and prolonged hypotension which was resistant to standard resuscitative measures. This may have contributed to the patient's eventual death.

\section{Case report}

A 68-year-old $52 \mathrm{~kg}$ asymptomatic female was admitted for elective right upper lobectomy for squamous cell cancer. The diagnosis had been established on the basis of a chest $x$-ray done for investigation of upper respiratory infection and subsequent transthoracic needle aspiration one month before the current admission. She had a past history of hypertension and mild congestive heart failure

\section{Key words}

ANAESTHETIC TECHNIQUES: regional, epidural; ANALGESICS: meperidine; COMPLICATIONS: hypotension.

From The Department of Anaesthesia, The Montreal General Hospital and McGill University, 1650 Cedar Avenue, Montreal, Quebec, Canada H3G 1 A4. Address correspondence to: Dr. P. Slinger and she was a heavy smoker with a 100 pack-year cigarette habit. There was no history of cerebral vascular disease. Preadmission medication consisted of: theophylline $300 \mathrm{mg}$ PO BID, dilitazem $60 \mathrm{mg}$ PO QID, digoxin $0.125 \mathrm{mg}$ PO QD, and ampicillin $500 \mathrm{mg}$ PO TID. The physical examination revealed bilateral carotid, abdominal and bilateral femoral bruits. Carotid artery doppler study revealed almost total right carotid artery stenosis. The electrocardiogram revealed nonspecific ST-T changes. A chest $x$-ray showed a right upper lobe mass and mild cardiomegaly. Pulmonary function tests showed $\mathrm{FEV}_{1} 1.85 \mathrm{~L}$, FVC $2.08 \mathrm{~L}$ with $\mathrm{FEV}_{\mathrm{l}} / \mathrm{FVC}$ ratio 0.89. Arterial blood gas analyses while breathing room air were pH 7.44, $\mathrm{PCO}_{2} 33 \mathrm{mmHg}, \mathrm{PO}_{2} 66 \mathrm{mmHg}, \mathrm{HCO}_{3} 23$ $\mathrm{mmol} \cdot \mathrm{L}^{-1}$. Renal profile revealed an elevated creatinine $249 \mathrm{mmol} \cdot \mathrm{L}^{-1}$ and a normal $\mathrm{BUN}$ of $7.1 \mathrm{mmol} \cdot \mathrm{L}^{-1}$. The patient was seen by the cardiology, vascular surgery and nephrology services. It was felt that the patient had chronic stable renal insufficiency. There was no indication for further investigation or treatment preoperatively.

The patient was given premedication with promethazine $25 \mathrm{mg}$ and glycopyrrolate $0.2 \mathrm{mg}$ IM. On arrival in the operating room intravenous and arterial lines were placed. The patient was preoxygenated and anaesthesia was induced with $100 \mathrm{mg}$ thiopentone and $200 \mu \mathrm{g}$ fentanyl followed by tracheo-bronchial intubation with a left $37 \mathrm{Fr}$ double-lumen tube after $80 \mathrm{mg}$ succinylcholine. Anaesthesia was maintained with isoflurane, oxygen and pancuronium. Immediately after induction of anaesthesia a pulmonary artery catheter was placed via the right internal jugular vein. The initial haemodynamic measurements were heart rate $80 \mathrm{bpm}$, blood pressure $150 / 80$ $\mathrm{mmHg}$, central venous pressure $11 \mathrm{mmHg}$, pulmonary artery pressure $32 / 17 \mathrm{mmHg}$, pulmonary capillary wedge pressure $14 \mathrm{mmHg}$. Blood gas analyses during two lung ventilation were $\mathrm{pH} 7.40, \mathrm{PaCO}_{2} 33 \mathrm{mmHg}, \mathrm{PaO}_{2} 539$ $\mathrm{mmHg}, \mathrm{HCO}_{3} 23 \mathrm{mmol} \cdot \mathrm{L}^{-1}$. The patient was haemodynamically stable during the two and a half hour operation. Total blood loss was $400 \mathrm{ml}$. The patient received 4 $\mathrm{L}$ of Ringer's lactate (RL) IV intraoperatively. The final 
intraoperative haematocrit was 32 per cent and urine output was $600 \mathrm{ml}$. After the surgical procedure was completed an epidural catheter was placed at the $T_{10}-T_{11}$ space directed cephalad following a negative pressure aspiration test for CSF and blood. No drugs were injected via the catheter at this time. The patient was transported to the surgical intensive care unit (SICU), awake, breathing spontaneously and haemodynamically stable.

In the SICU the initial assessment showed a systolic blood pressure $140 \mathrm{mmHg}$, pulse $86 \mathrm{bpm}, \mathrm{CO} 4.2$ $\mathrm{L} \cdot \min ^{-1}, \mathrm{CI} 2.6 \mathrm{~L} \cdot \mathrm{min}^{-1}$, SVR 1810 dynes $\cdot \mathrm{sec} \cdot \mathrm{cm}^{-5}$, CVP $6 \mathrm{mmHg}$, PCWP $7 \mathrm{mmHg}$. Her postoperative course was initially marked by poor urine output which was presumed to be prerenal in origin. It was felt that the fluid losses had possibly been underestimated. The patient received IV volume challenges totalling $1500 \mathrm{ml}$ crystalloid and the PCWP increased from $7 \mathrm{mmHg}$ to $14 \mathrm{mmHg}$. Despite fluid, dopamine $3 \mu \mathrm{g} \cdot \mathrm{kg}^{-1} \mathrm{~min}^{-1}$, and repeated doses of furosemide: $(40 \mathrm{mg}+80 \mathrm{mg}+500 \mathrm{mg}$ ) in the first eight hours postoperatively, she remained oliguric with an urine output of $15-20 \mathrm{ml} \cdot \mathrm{hr}^{-1}$. The patient was haemodynamically stable during this period with a systolic blood pressure between 120 and $150 \mathrm{mmHg}$. A pulse oximeter was used to monitor $\mathrm{O}_{2}$ saturation which remained $>95$ per cent throughout this period.

The patient received epidural narcotics for postoperative pain. The initial dose was $25 \mu \mathrm{g}$ sufentanil in $10 \mathrm{ml}$ of normal saline, administered on request two hours after the trachea was extubated. The assessment of analgesic effect was based on the patient's subjective report and was considered good because she was free of pain. The analgesic effect lasted four hours. The second analgesic administration consisted of $50 \mathrm{mg}$ preservative-free meperidine in $10 \mathrm{ml}$ of normal saline solution which gave good analgesia for another three and a half hours. Both epidural administrations had been uneventful.

Five minutes after the third analgesic administration of $50 \mathrm{mg}$ meperidine in $10 \mathrm{ml}$ of normal saline solution the systolic blood pressure decreased from $150 \mathrm{mmHg}$ to 40 $\mathrm{mmHg}$. The rapid development of hypotension was followed by progressive respiratory depression. Initially, the patient was drowsy but remained responsive to verbal stimuli. Over the next $10 \mathrm{~min}$ she became unable to maintain her airway in the absence of jaw support and her lungs were ventilated with 100 per cent oxygen and the trachea was intubated. Aspiration of the epidural catheter was negative for blood or cerebral spinal fluid (CSF). A double-check of the medication revealed that the appropriate ampoule of meperidine had been administered.

The decrease in BP was associated with sinus tachycardia of $160 \mathrm{bpm}$ with multiple PVC's and $3 \mathrm{~mm} \mathrm{ST}$ segment depression. The hypotension did not respond to divided doses of naloxone ( $0.8 \mathrm{mg}$ total dose), ephedrine
(100 $\mathrm{mg}$ total dose) or to $1 \mathrm{~L} \mathrm{RL}$ during the initial $5 \mathrm{~min}$. One ampoule ( $44 \mathrm{meq})$ of sodium bicarbonate was administered followed by repeated boluses of $100 \mu \mathrm{g}$ phenylephrine and a dopamine infusion at a rate of 10 $\mu \mathrm{g} \cdot \mathrm{kg}^{-1} \cdot \mathrm{min}^{-1}$. Another $1.5 \mathrm{~L} \mathrm{RL}$ solution was administered over the next ten minutes and another ampoule of bicarbonate.

During the hypotensive crisis no blood loss was identified. A nasogastric tube was inserted and $100 \mathrm{ml}$ of clear gastric fluid was drained. Both chest tubes functioned well and a chest $x$-ray ruled out pneumothorax. After half an hour of resuscitative measures the systolic blood pressure reached $50 \mathrm{mmHg}$ and heart rate $138 \mathrm{bpm}$ with occasional ventricular ectopic beats. Haematocrit measured at the end of the first half hour was 22 per cent and two units of packed red cells were administered over the next half hour. After the first hour of resuscitative measures systolic BP was $106 \mathrm{mmHg}$ and $\mathrm{HR}$ was 140 $\mathrm{bpm}$. The pupils were fully dilated but responsive to light. After two hours the BP reached $140 \mathrm{mmHg}$ and the patient was drowsy but easily arousable. The trachea was still intubated. The patient was breathing spontaneously through a T-piece on 40 per cent oxygen and tolerating the tube well. Her lungs were clear to auscultation. Initial ST-T changes consistent with inferior wall ischaemia had resolved when an ECG was done after two hours. She was extubated after six hours. No neurological deficit was recorded. During the first 24 hours after the operation the patient received $9 \mathrm{~L}$ of crystalloid fluid plus two units of blood. The haematocrit was 33 per cent and the total output of urine in first $24 \mathrm{hr}$ was $1.0 \mathrm{~L}$. After the hypotensive crisis had resolved the patient was haemodynamically stable. Further PCWP was kept in the range of $10-14 \mathrm{mmHg}$. The time course of the circulatory failure, haemodynamic variables and blood gases measurements during resuscitation are displayed in the Table.

The second day after surgery, the patient remained afebrile. There were no significant elevations of white blood cell count or serum creatine kinase MB isoenzyme or serum digoxin level. Blood, sputum and urine bacterial cultures were negative. The serum creatinine increased to $419 \mathrm{mmol} \cdot \mathrm{L}^{-1}$ and $B U N$ to $40 \mathrm{mmol} \cdot \mathrm{L}^{-1}$. The plan was to ultra filtrate the patient.

The third day arterial blood gas measurements deteriorated overnight and the chest $x$-ray showed interstitial and alveolar oedema. The patient developed respiratory distress and died in acute pulmonary oedema unresponsive to resuscitative measures. Permission for autopsy was refused.

\section{Discussion}

The first striking characteristic of this case was the unexpected, acute, severe hypotension, temporally rela- 
TABLE Time course of circulatory failure after second injection of epidural meperidine

\begin{tabular}{|c|c|c|c|c|}
\hline Variable & Pre-injection & $\begin{array}{l}\text { Post-injection } \\
30 \text { minutes }\end{array}$ & $\begin{array}{l}\text { Post-injection } \\
\text { one hour }\end{array}$ & $\begin{array}{l}\text { Post-injection } \\
\text { two hours }\end{array}$ \\
\hline SBP (mmHg) & 140 & 50 & 106 & 140 \\
\hline $\mathrm{CVP}(\mathrm{mmHg})$ & 10 & 2 & 11 & 13 \\
\hline PCWP (mmHg) & 14 & 6 & 14 & 15 \\
\hline $\operatorname{CO}\left(1 \cdot \min ^{-1}\right)$ & 3.9 & 5.7 & 4.2 & 4.3 \\
\hline $\mathrm{CI}\left(1 \mathrm{~min}^{-1} \cdot \mathrm{m}^{-2}\right)$ & 2.4 & 3.7 & 2.6 & 2.7 \\
\hline SVR (dyne $\cdot \mathrm{s} \cdot \mathrm{cm}^{-5}$ ) & 1683 & 771 & 1361 & 1870 \\
\hline HR (beats $\cdot \min ^{-1}$ ) & 98 & 144 & 142 & 139 \\
\hline $\mathrm{F}_{1} \mathrm{O}_{2}$ & 0.21 & 1.0 & 1.0 & 0.40 \\
\hline $\mathrm{PO}_{2}(\mathrm{mmHg})$ & 70 & 112 & 175 & 200 \\
\hline $\mathrm{PCO}_{2}(\mathrm{mmHg})$ & 42 & 39 & 29 & 26 \\
\hline $\mathrm{SaO}_{2}(\mathscr{\%})$ & 98 & 97 & 100 & 100 \\
\hline $\mathrm{HCO}_{3}\left(\mathrm{mmol} \mathrm{1} \mathrm{l}^{-1}\right)$ & 22 & 15 & 18 & 23 \\
\hline $\mathrm{pH}$ & 7.32 & 7.21 & 7.47 & 7.52 \\
\hline
\end{tabular}

$\mathrm{SBP}=$ systolic blood pressure, $\mathrm{SaO}_{2}=$ arterial oxygen saturation.

ted to the epidural injection of $50 \mathrm{mg}$ meperidine in $10 \mathrm{ml}$ of normal saline solution. The decision to change from epidural sufentanil to epidural meperidine was due to the lack of familiarity of the ICU staff with epidural sufentanil. Meperidine is the epidural opioid used most frequently in our intensive care unit due to its extremely low incidence of delayed respiratory depression. ${ }^{2}$ The hypotension could have been caused by one of several mechanisms:

First, the cause could have been systemic absorption of meperidine from the epidural space. Normally after injection into the epidural space, meperidine is rapidly absorbed both systemically and into the CSF. The concentrations in blood and CSF are directly proportional to the dose injected ${ }^{3}$ (in this case $1 \mathrm{mg} \cdot \mathrm{kg}^{-1}$ ). The blood concentration after administration of $50-100 \mathrm{mg}$ meperidine in the epidural space can reach analgesic levels of $0.2-0.7 \mu \mathrm{g} \cdot \mathrm{ml}^{-1}$ within $20 \mathrm{~min}$, although there is high individual variability. ${ }^{3,4}$ The fraction of the dose crossing the dura has been calculated to be 3.7 per cent for meperidine. ${ }^{5}$ The rest of the epidural meperidine is taken up systemically via the epidural venous plexus or via non-neuronal tissue.

The second possibility might be inadvertent intravascular injection of meperidine into epidural vessels. Even after one or two normal injections, the migration of the catheter into an epidural vessel may not be recognized by an aspiration test. Ravindran et al. ${ }^{6}$ reported an adverse reaction due to inadvertent intravascular injection following three normal epidural injections of $10 \mathrm{ml}$ of $0.75 \mathrm{per}$ cent bupivacaine solution, but this has not been reported with epidural administration of narcotics. Meperidine has negative inotropic and positive chronotropic effects on the heart. If IV injection is accompanied by histamine release this would contribute to meperidine induced hypotension. ${ }^{7}$
The third possible cause of meperidine-induced hypotension is extensive spinal or epidural anaesthetic blockade. Inadvertent subarachnoid or subdural injection can follow migration of the catheter. ${ }^{8,9}$ Meperidine has some local anaesthetic effect and has been used as a spinal anaesthetic agent. ${ }^{10}$ However, with epidural narcotics there has been no proven sympathetic blockade. Glynn et al. found no evidence of sympathetic blockade with epidural meperidine by using plethysmography to demonstrate an unchanged skin blood flow. ${ }^{3}$

Recent pharmacokinetic data regarding epidural meperidine show the persistence of meperidine in CSF between 12 and $24 \mathrm{hr},{ }^{5}$ which could be due to a slow release of lipophilic drug from subarachnoid nervous tissue. This could cause a cumulative effect with repeated doses. The CSF concentration of meperidine at the time of request for additional analgesia varies greatly. ${ }^{11}$

Another striking feature of this case was that the hypotension was unresponsive to naloxone and standard resuscitative measures. Torda et al. ${ }^{12}$ reported one severely ill patient who had undergone repair of a thoracic aortic aneurysm and who developed hypotension which appeared to be related to epidural morphine administration and which responded to naloxone. Robinson et al. ${ }^{13}$ reported hypotension following epidural administration of meperidine in patients after narcotic anaesthesia with fentanyl had been given during cardiac surgery. This was easily corrected by infusion of crystalloids without pharmacological support. All other reports emphasize the circulatory stability with epidural opioids.

There were many other factors which may have contributed to the cardiovascular collapse in this patient. We feel the collapse was related to the epidural meperidine because of the temporal relationship and because most other likely causes were excluded. 
The patient was normovolaemic, as documented by the haemodynamic variables prior to the final epidural meperidine injection. There were no clinical or laboratory findings to support a diagnosis of anaphylaxis, sepsis or toxins. It is unclear why the hypotension was relatively resistant to vasopressors but epinephrine might have been a more appropriate choice in this situation. ${ }^{14}$ The lack of response to naloxone suggests that the hypotension was not mediated by the usual opioid agonist-receptor interaction.

In conclusion, the anaesthetists' challenge in prevention of postoperative pain is made more difficult in the presence of a sick patient with limited physiological reserves. Even when two injections of opioids through the epidural catheter have been uneventful, this does not guarantee that the next administration will be uneventful. Epidural meperidine may have cardiovascular side-effects which can be life-threatening especially in critically ill patients. The high-risk patient for general anaesthesia may also be a high-risk patient for postoperative epidural meperidine analgesia. A continuous epidural infusion may decrease some of the risks and side-effects associated with bolus injections. The advantage of epidural analgesia has to be balanced against the associated morbidity of the technique in each patient.

\section{Acknowledgments}

The authors thank Dr. J. Ramsay for his review of the manuscript and Miss C. Colligan for her secretarial assistance.

\section{References}

1 Yeager MD, Glass $D D$, Neff $R K$, Brinck-Johnsen

$T$. Epidural anesthesia and analgesia in high-risk surgical patients. Anesthesiology 1987; 66: 729-36.

2 Cousins MJ, Mather $L E$. Intrathecal and epidural administration of opioids. Anesthesiology 1984; 61: 276-310.

3 Glynn CJ, Mather LE, Cousins MJ, Graham JR, Wilson $P R$. Peridural meperidine in humans: analgetic response, pharmacokinetics, and transmission into CSF. Anesthesiology 1981; 55; 520-6.

4 Acalovischi I, Ene $V$, Lorinczi E. Nicolaus $F$. Saddle block with pethidine for perineal operations. Br J Anaesth 1986; 58: 1012-6.

5 Sjcstrom S. Hartvig P, Persson P, Tamsen A. Pharmacokinetics of epidural morphine and meperidine in humans. Anesthesiology 1987; 67: 877-88.

6 Ravindran R, Albrecht W, McKay M. Apparent intravascular migration of epidural catheter. Anesth Analg 1979; 58: 252-3.

7 Flacke JW, Flacke WE, Bloor BC, Van Etten AP, Kripke $B J$. Histamine release by four narcotics: a double-blind study in humans. Anesth Analg 1987; 66: 723-30.
8 Lubenow $T$, Keh-Wong $E$, Kristof $K$, Ivankovich $O$, Ivankovich $A D$. Inadvertent subdural injection: a complication of an epidural block. Anesth Analg 1988; 67: 175-9.

9 Savolaine ER, Pandya JB, Greenblatt SH, Conover $S R$. Anatomy of the human lumbar epidural space. New insights using CT-epidurography. Anesthesiology 1988; 68: 217-20.

10 Sangarlangkarn S, Klaewtanong V, Jonglerttrakool $P$, Khankaew $V$. Meperidine as a spinal anesthetic agent: a comparison with lidocaine-glucose. Anesth Analg 1987; 66: $235-40$.

11 Cousins MJ. Comparative pharmacokinetics of spinal opioids in humans: a step toward determination of relative safety. Anesthesiology 1987; 67: 875-6.

12 Torda TA, Pybus DA. Clinical experience with epidural morphine. Anesth Intens Care 1981; 9: 129-34.

13 Robinson RJS, Brister S, Jones E, Quigley $M$. Epidural meperidine analgesia after cardiac surgery. Can Anaesth Soc J 1986; 33: 550-5.

14 Caplan RA, Ward RI, Posner K, Cheney FW. Unexpected cardiac arrest during spinal anesthesia: a closed claims analysis of predisposing factors. Anesthesiology 1988; 68: 5-11.

\section{Résumé}

Une patiente de soixante huit ans a développé une hypotension sévère immédiatement après l' administration de mépéridine par voie épidurale pour le traitement de sa douleur post thoraco. tomie. Les deux injections précédentes d'opiacés par voie épidurale furent sans complications. Le collapse cardiovasculaire qui s'en suivi a été difficile a traiter et peut a avoir contribué au décès de la patiente. Les complications cardiovasculaires ne sont pas fréquemment décrites comme effects secondaires possibles de la thérapie aux opiacés par voie épidurale. 